\title{
Seasonal and Spatial Patterns of Mercury Wet Deposition in the United States: Constraints on the Contribution from North American Anthropogenic Sources
}

\section{Citation}

Selin, Noelle E., and Daniel J. Jacob. 2008. Seasonal and spatial patterns of mercury wet deposition in the United States: Constraints on the contribution from North American anthropogenic sources. Atmospheric Environment 42(21): 5193-5204.

\section{Published Version}

doi:10.1016/j.atmosenv.2008.02.069

\section{Permanent link}

http://nrs.harvard.edu/urn-3:HUL.InstRepos:3554407

\section{Terms of Use}

This article was downloaded from Harvard University's DASH repository, and is made available under the terms and conditions applicable to Other Posted Material, as set forth at http:// nrs.harvard.edu/urn-3:HUL.InstRepos:dash.current.terms-of-use\#LAA

\section{Share Your Story}

The Harvard community has made this article openly available.

Please share how this access benefits you. Submit a story.

\section{Accessibility}




\title{
Seasonal and spatial patterns of mercury wet deposition in the United States: Constraints on the contribution from North American anthropogenic sources
}

\author{
Noelle E. Selin*, Daniel J. Jacob \\ Department of Earth and Planetary Sciences and School of Engineering and Applied Sciences, Harvard University, Cambridge, MA, USA
}

Received 6 November 2007; received in revised form 28 February 2008; accepted 29 February 2008

\begin{abstract}
Observed wet deposition fluxes of mercury in the United States show a maximum in the Southeast, and a consistent seasonal variation (maximum in summer, minimum in winter) that increases in amplitude from north to south. We simulate these patterns successfully with a global 3-D chemical transport model (GEOS-Chem) including our best estimates of sources and processes. We attribute the high wet deposition over the Southeast in summer to scavenging of upper-altitude $\mathrm{Hg}(\mathrm{II})$ by deep convection. Seasonal variation at higher latitudes is attributed to a combination of enhanced summertime oxidation of $\mathrm{Hg}(0)$ and inefficient scavenging of $\mathrm{Hg}(\mathrm{II})$ by snow. Scavenging of $\mathrm{Hg}(\mathrm{II})$ from above the boundary layer contributes over half of wet deposition to the US in the model. Even within the boundary layer, we find that most of $\mathrm{Hg}(\mathrm{II})$ originates from the global mercury pool. Wet deposition in the model accounts for only $30 \%$ of total mercury deposition in the US, the remainder being from dry deposition, including $42 \%$ from $\mathrm{Hg}(0)$ uptake. North American anthropogenic emissions contribute $20 \%$ of total mercury deposition in the US (up to $50 \%$ in the industrial Midwest and Northeast).
\end{abstract}

(C) 2008 Elsevier Ltd. All rights reserved.

Keywords: Mercury; Wet deposition; United States; Downwelling

\section{Introduction}

Regulation of mercury emissions in the United States aims to reduce the deposition of mercury to domestic ecosystems. Global modeling studies indicate that most of this deposition originates in

\footnotetext{
*Corresponding author at: Department of Earth, Atmospheric and Planetary Sciences, Massachusetts Institute of Technology, 77 Massachusetts Avenue, Building 54-1715, Cambridge, MA 02139-4307, USA. Tel.: + 16173242592 ; fax: + 16172530354.

E-mail address: selin@mit.edu (N.E. Selin).
}

fact from emissions outside North America (Seigneur et al., 2004; Selin et al., 2007; Strode et al., 2007, 2008), but there are large uncertainties in model representations of mercury chemistry and deposition processes. We use here data from the national mercury deposition network (MDN) (National Atmospheric Deposition Program, 2007) to test the ability of a global 3-D model (GEOS-Chem) to reproduce observed seasonal as well as spatial wet deposition patterns, and from there to better quantify the sources of mercury deposition in the United States. 
Mercury is emitted to the atmosphere in gaseous elemental form $\operatorname{Hg}(0)$, in semivolatile oxidized form $\mathrm{Hg}(\mathrm{II})$, and in nonvolatile particulate form $\mathrm{Hg}(\mathrm{P})$. $\mathrm{Hg}(0)$ has a long (0.5-2 yr) atmospheric lifetime and represents a globally well-mixed mercury pool; it is eventually oxidized to $\mathrm{Hg}(\mathrm{II})$, which is highly watersoluble and readily deposited. Deposition of emitted $\mathrm{Hg}(\mathrm{II})$ and $\mathrm{Hg}(\mathrm{P})$ can directly affect the region of emission, although $\mathrm{Hg}(\mathrm{II})$ can also be reduced to $\mathrm{Hg}(0)$ and enter the global pool. Anthropogenic emission of mercury from North America is mostly from coal combustion; about half is as $\operatorname{Hg}(0)$ and half is as $\mathrm{Hg}(\mathrm{II})+\mathrm{Hg}(\mathrm{P})$ (Pacyna et al., 2006). Considering that North America accounts for only $7 \%$ of global anthropogenic emission of mercury (2000 statistics) (Pacyna et al., 2006), any diagnosis of regional vs. global contributions to mercury deposition must focus on the fate of the emitted $\mathrm{Hg}(\mathrm{II})+\mathrm{Hg}(\mathrm{P})$ and on the supply of $\mathrm{Hg}(\mathrm{II})$ by oxidation of $\mathrm{Hg}(0)$ from the global pool.

Previous analyses of wet deposition data have reached conflicting conclusions regarding the relative contributions of domestic vs. global contributions to mercury deposition in different US regions (Dvonch et al., 1998, 2005; Guentzel et al., 2001; Keeler et al., 2006b; Vanarsdale et al., 2005). We show here that the observed seasonal variation of mercury deposition and its latitudinal gradient provide important constraints on this problem when interpreted with a global 3-D model. We focus our analysis on MDN data for 2004-2005, the two most recent years of data available and with the best coverage.

\section{Model description}

The GEOS-Chem atmosphere-land-ocean mercury simulation is described by Selin et al. (2008). We use here GEOS-Chem version 7.04 (http://www. as.harvard.edu/chemistry/trop/geos) (Bey et al., $2001)$ at $4^{\circ} \times 5^{\circ}$ resolution with assimilated meteorological data for 2004-2005 from the NASA Goddard Earth Observing System (GEOS-4). Three mercury species $(\mathrm{Hg}(0), \mathrm{Hg}(\mathrm{II})$, and $\mathrm{Hg}(\mathrm{P}))$ are transported in the atmosphere. Anthropogenic emissions are from the GEIA inventory for the year 2000 (Pacyna et al., 2006), modified as described in Selin et al. (2008) to satisfy global observational constraints. These modifications include a $50 \%$ increase in $\mathrm{Hg}(0)$ in Asia (now $1939 \mathrm{Mg} \mathrm{yr}^{-1}$ total $\mathrm{Hg}$ ), a $30 \%$ increase in the rest of the world (now $1011 \mathrm{Mg} \mathrm{yr}^{-1}$ ), and addition of emissions from biomass burning $\left(600 \mathrm{Mg} \mathrm{yr}^{-1}\right)$ and artisanal mining (450 $\left.\mathrm{Mg} \mathrm{yr}^{-1}\right)$. The total emissions from anthropogenic sources and biomass burning are thus $4000 \mathrm{Mg} \mathrm{yr}^{-1}$. Atmosphere-ocean coupling is treated with a slab model for the ocean including cycling between $\mathrm{Hg}(0), \mathrm{Hg}(\mathrm{II})$, and nonreactive mercury in the oceanic mixed layer (Strode et al., 2007). Atmosphere-land coupling includes partial recycling of deposited $\mathrm{Hg}$ (II) and mobilization of long-lived soil mercury through volatilization and evapotranspiration (Selin et al., 2008). Mercury is volatilized from the land and oceans exclusively as $\mathrm{Hg}(0)$; direct emission of $\mathrm{Hg}(\mathrm{II})$ and $\mathrm{Hg}(\mathrm{P})$ is solely anthropogenic.

Atmospheric oxidation of $\mathrm{Hg}(0)$ to $\mathrm{Hg}(\mathrm{II})$ in the model takes place by $\mathrm{OH}\left(k=9 \times 10^{-14} \mathrm{~cm}^{3} \mathrm{~s}^{-1}\right.$, Sommar et al., 2001; Pal and Ariya, 2004) and $\mathrm{O}_{3}$ $\left(k=3 \times 10^{-20} \mathrm{~cm}^{3} \mathrm{~s}^{-1}\right.$, Hall, 1995). In-cloud (aqueous) photochemical reduction of $\mathrm{Hg}(\mathrm{II})$ to $\mathrm{Hg}(0)$ is included to accommodate observational constraints on global mercury atmospheric concentrations and seasonal variation at northern mid-latitudes (Selin et al., 2007). $\mathrm{Hg}(\mathrm{P})$ is considered chemically inert and is removed by deposition. Fast $\mathrm{Hg}$ (II) reduction in power plant plumes (Lohman et al., 2006) remains hypothetical and is not included in the model.

Fig. 1 shows the spatial distribution of $\mathrm{Hg}(0)$, $\mathrm{Hg}(\mathrm{II})$ and $\mathrm{Hg}(\mathrm{P})$ anthropogenic emissions in North America in GEOS-Chem, at the original $1^{\circ} \times 1^{\circ}$ resolution of Pacyna et al. (2006). $\mathrm{Hg}(\mathrm{II})$ and $\mathrm{Hg}(\mathrm{P})$ represent, respectively, $33 \%$ and $14 \%$ of the total mercury emission of $169 \mathrm{Mg} \mathrm{yr}^{-1}$ for the domain of Fig. 1. Emissions are highest in the industrial Midwest (Illinois, Indiana, Ohio, Kentucky, Pennsylvania, and West Virginia) due to coal combustion, but high values are generally found in population centers due to additional sources from waste incineration and industrial processes. Some high values in the West (notably in northern Nevada) are from gold mining.

Mercury deposition processes are of particular interest here. GEOS-Chem includes wet and dry deposition of $\mathrm{Hg}(\mathrm{II})$ and $\mathrm{Hg}(\mathrm{P})$, as well as dry deposition of $\mathrm{Hg}(0)$. Wet deposition of $\mathrm{Hg}(\mathrm{II})$ and $\mathrm{Hg}(\mathrm{P})$ includes rainout and washout from largescale and convective precipitation, and scavenging in convective updrafts (Liu et al., 2001; Selin et al., 2008). $\mathrm{Hg}(\mathrm{P})$ is scavenged as a water-soluble aerosol (Liu et al., 2001), while $\mathrm{Hg}$ (II) is scavenged as a highly water-soluble gas. $\mathrm{Hg}(\mathrm{II})$ is released to the gas phase when water freezes (zero retention 


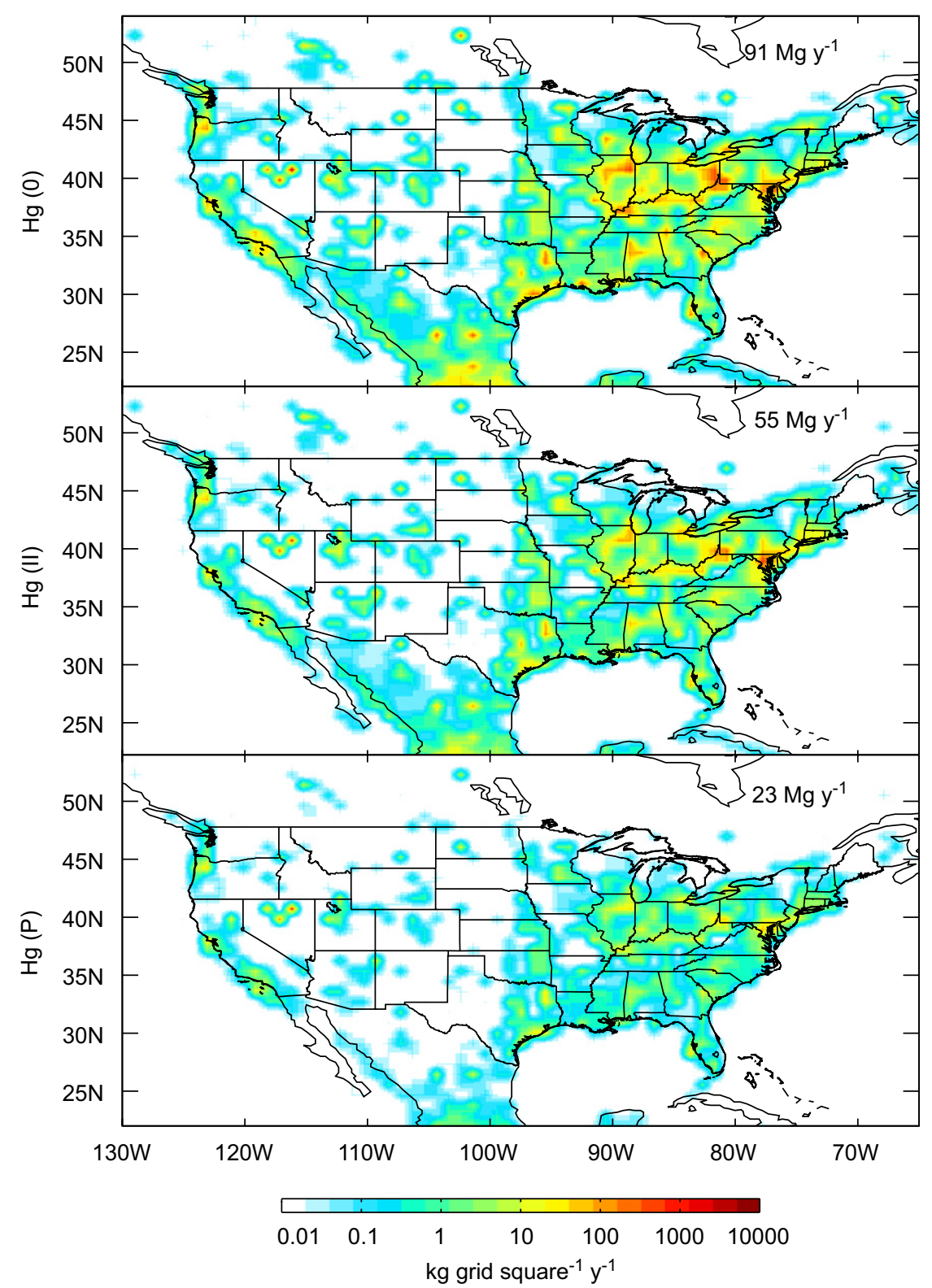

Fig. 1. Annual anthropogenic emissions of $\mathrm{Hg}(0), \mathrm{Hg}(\mathrm{II})$, and $\mathrm{Hg}(\mathrm{P})\left(\mathrm{kg} \mathrm{yr}^{-1}\right.$ per $1^{\circ} \times 1^{\circ}$ grid square $)$ in North America for 2000 . Data are from Pacyna et al. (2006), increased by $30 \%$ for input to GEOS-Chem (Selin et al., 2008). Totals are shown in the inset for the domain of the figure. A $1^{\circ} \times 1^{\circ}$ grid square corresponds to $70 \mathrm{~km}$ longitude $\times 100 \mathrm{~km}$ latitude at $45^{\circ} \mathrm{N}$.

efficiency).We assume no scavenging of $\mathrm{Hg}(\mathrm{II})$ by frozen precipitation, consistent with limited field observations (Keeler et al., 2006a). As we will see, this is needed in the model to reproduce the observed winter minimum in $\mathrm{Hg}$ deposition at northern latitudes. Dry deposition of $\mathrm{Hg}(0), \mathrm{Hg}(\mathrm{II})$ and $\mathrm{Hg}(\mathrm{P})$ to land are described with the Wesely (1989) resistance-in-series scheme as adapted by Wang et al. (1998) for global modeling. Dry deposition of $\operatorname{Hg}(0)$ to land is determined in that scheme by its Henry's law constant $\left(0.11 \mathrm{M} \mathrm{atm}^{-1}\right.$ (Lin and Pehkonen, 1999)). Dry deposition of $\mathrm{Hg}(0)$ to the ocean is determined by the standard two-film exchange parameterization (Strode et al., 2007).

Our previous model (Selin et al., 2008) assumed zero surface resistance for $\mathrm{Hg}(\mathrm{II})$ dry deposition, based on some observations of very high deposition velocities $\left(>5 \mathrm{~cm} \mathrm{~s}^{-1}\right)$ to vegetated areas (Poissant et al., 2005; Lindberg and Stratton, 1998). This resulted in an underestimate of wet deposition in the 
Midwest compared to the MDN data, as regionally emitted $\mathrm{Hg}$ (II) was then mainly removed by dry deposition. Here we correct this model bias by including a surface resistance for $\mathrm{Hg}$ (II) based on a Henry's law constant of $1 \times 10^{6} \mathrm{M} \mathrm{atm}^{-1}$ for $\mathrm{HgCl}_{2}$ (Lin and Pekhonen, 1999), which is thought to be the most thermodynamically favorable form (Seigneur et al., 1994; Lindberg et al., 2007). The resulting dry deposition velocity of $\mathrm{Hg}(\mathrm{II})$ to vegetated areas in summer daytime is typically in the range $1.5-2 \mathrm{~cm} \mathrm{~s}^{-1}$.

Decreasing the rate of $\mathrm{Hg}(\mathrm{II})$ dry deposition in the model increases the overall total gaseous mercury (TGM) lifetime against deposition. In order to maintain the same concentration of TGM to match global observations as in Selin et al. (2008), we decrease here the rate of in-cloud $\mathrm{Hg}$ (II) reduction by a factor of 2 , corresponding to a mean in-cloud lifetime of $40 \mathrm{~min}$ for dissolved $\mathrm{Hg}$ (II). This is a particularly uncertain aspect of the chemistry mechanism, constrained by Selin et al. (2007) to match the seasonal observation of TGM at northern midlatitudes but since found by Selin et al. (2008) to likely be too high once the seasonal variation of the soil source is taken into account. Decreasing this reduction rate constant by a factor of 2 not only maintains consistency between simulated and observed concentrations on a global scale but also improves the simulation of the spatial pattern in the MDN data.

Total deposition of mercury over the US in GEOS-Chem on an annual basis thus includes $42 \%$ from $\mathrm{Hg}(0)$ dry deposition, $26 \%$ from $\mathrm{Hg}(\mathrm{II})$ dry deposition, $2 \%$ from $\mathrm{Hg}(\mathrm{P})$ dry deposition, $27 \%$ from $\mathrm{Hg}(\mathrm{II})$ wet deposition, and $3 \%$ from $\mathrm{Hg}(\mathrm{P})$ wet deposition. Wet deposition as measured by the MDN data accounts for only $30 \%$ of total mercury deposition according to the model.

\section{Wet deposition patterns}

\subsection{Spatial distribution}

Fig. 2 shows the measured annual average wet deposition flux of mercury from MDN for 2004-2005 (top panel, circles), including all 57 sites having at least 320 days of data in each of the 2 years. (A list of the 57 sites used is available as online supplemental information.) Values are higher in the East than in the West, mostly reflecting higher precipitation in the East. The MDN data in the East show a strong latitudinal gradient with values decreasing from $16-20 \mu \mathrm{g} \mathrm{m}^{-2} \mathrm{yr}^{-1}$ in the Southeast to $8-10 \mu \mathrm{g} \mathrm{m}^{-2} \mathrm{yr}^{-1}$ in the Midwest/mid-Atlantic region and $4-8 \mu \mathrm{g} \mathrm{m}^{-2} \mathrm{yr}^{-1}$ in the Northeast and Canada. The latitudinal gradient explains $60 \%$ of the variation in the MDN data $\left(r^{2}=0.6\right)$ for 2004-2005, and is reproducible for all years in the MDN record (1996-2005). A latitudinal gradient from the Northeast US to Canada in the MDN data for 1996-2002 was previously reported by Vanarsdale et al. (2005), who attributed it to increasing distance from sources. However, such an explanation cannot account for the highest MDN values in the Southeast.

The large-scale spatial patterns in the MDN data are generally well reproduced by GEOS-Chem (Fig. 2 , top panel). The mean bias relative to the annual average $2004-2005$ observations is $-1.7 \%$, and the model and data show good spatial correlation $\left(r^{2}=0.73\right)$. This is improved over the previous simulation of Selin et al. (2008), which had a mean bias of $-17 \%$ with $r^{2}=0.60$. Selin et al. (2008) reproduced the latitudinal gradient in the East, but underestimated the magnitude of deposition in the Midwest/mid-Atlantic region. Bullock et al. (2007) reported $r^{2}$ values between 0.45 and 0.7 for simulated-to-observed wet deposition flux for three regional models in an intercomparison study. The improvement here results from the decrease in the $\mathrm{Hg}(\mathrm{II})$ dry deposition velocity, allowing for greater wet deposition, as discussed in the previous section. The main discrepancy between model and observations in Fig. 2 is that the model maximum is in Texas/Louisiana, while in the observations it is in Florida. This likely reflects model error in the regional distribution of $\mathrm{Hg}(\mathrm{II})$ downwelling and will be discussed further below.

The middle and bottom panels of Fig. 2 show the contributions to wet deposition from domestic (North American anthropogenic) vs. external sources in the model, as diagnosed in the model by a simulation with North American anthropogenic sources only. The contribution from external sources dominates except in the industrial Midwest and Northeast, where it is comparable to the contribution from domestic sources; this will be discussed further in Section 4. The observed latitudinal gradient in the East is almost entirely explained by the external contribution and this is discussed below.

\subsection{Seasonal variation}

Fig. 3 shows the observed and simulated seasonal variations of the wet deposition flux for 2004-2005 


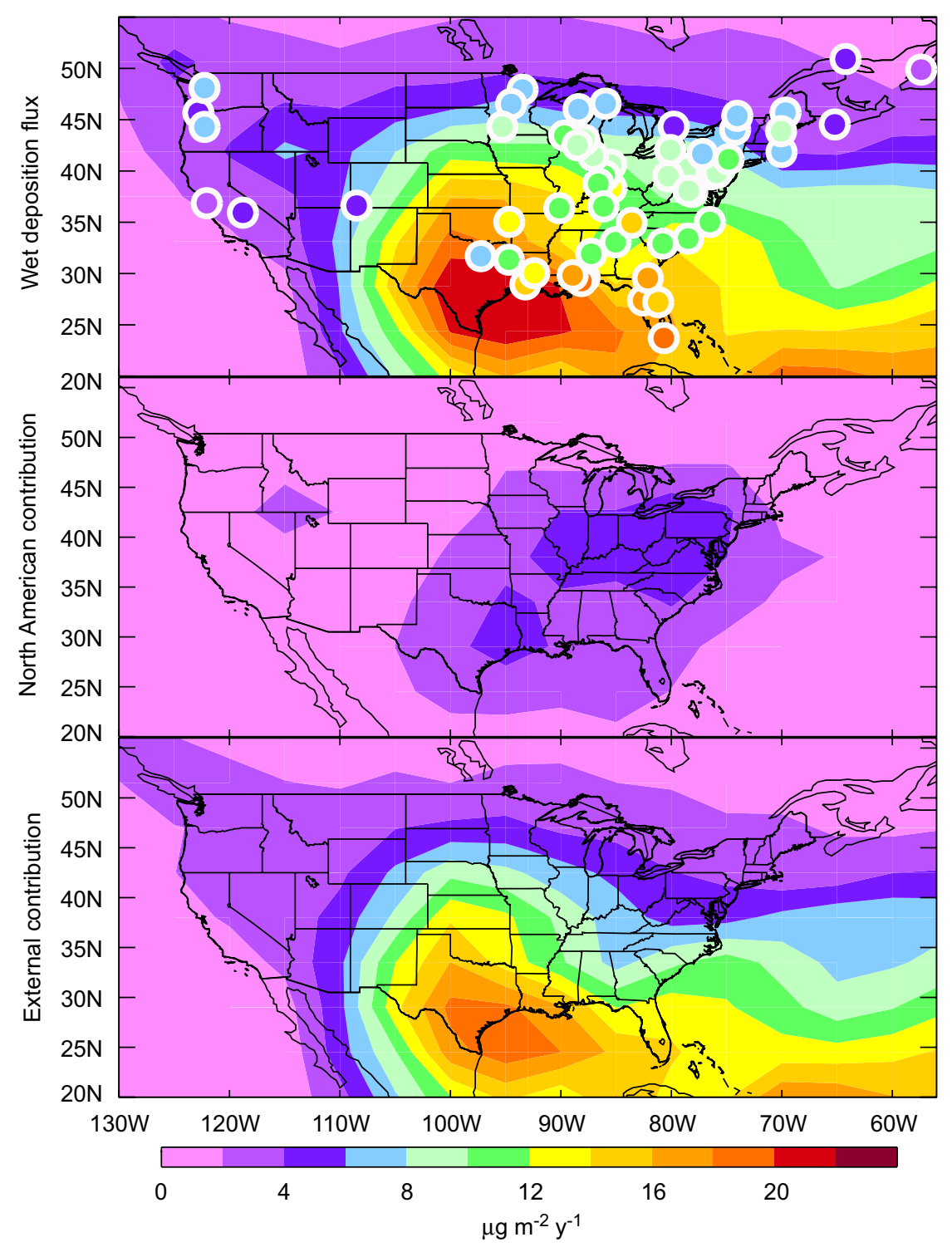

Fig. 2. Annual mean wet deposition flux of mercury over the United States for 2004-2005 $\left(\mu \mathrm{g} \mathrm{m}^{-2} \mathrm{yr}^{-1}\right)$. Top panel: Observations from 57 sites of the Mercury Deposition Network (MDN) (circles) compared to GEOS-Chem model results (background). The list of MDN sites is available as online supplemental information. Middle panel: contribution to this wet deposition flux from anthropogenic North American sources in the model, as obtained by difference from a sensitivity simulation with all other sources shut off; lower panel: contribution from external sources determined by the sensitivity simulation. North America is defined as the geographical domain shown in the figure.

in different latitudinal bands of the eastern US. Also shown is the model contribution from North American anthropogenic sources. There is strong seasonal variation in the observations, with a maximum in summer and minimum in winter. Different explanations for this seasonal variation in the literature include more precipitation in summer (Glass and Sorensen, 1999; Guentzel et al., 2001), less efficient scavenging of mercury by snow than by rain (Glass and Sorensen, 1999;
Mason et al., 2000), and enhanced $\operatorname{Hg}(0)$ oxidation to $\mathrm{Hg}$ (II) in summer (Mason et al., 2000). Emissions of $\mathrm{Hg}(\mathrm{II})$ and $\mathrm{Hg}(\mathrm{P})$, which are exclusively anthropogenic, do not have significant seasonal variation (NEI, 1999).

Fig. 3 shows that the observed amplitude of seasonal variation has a strong latitudinal dependence, decreasing with increasing latitude. To our knowledge this has not been reported before, though Mason et al. (2000) previously noted that 


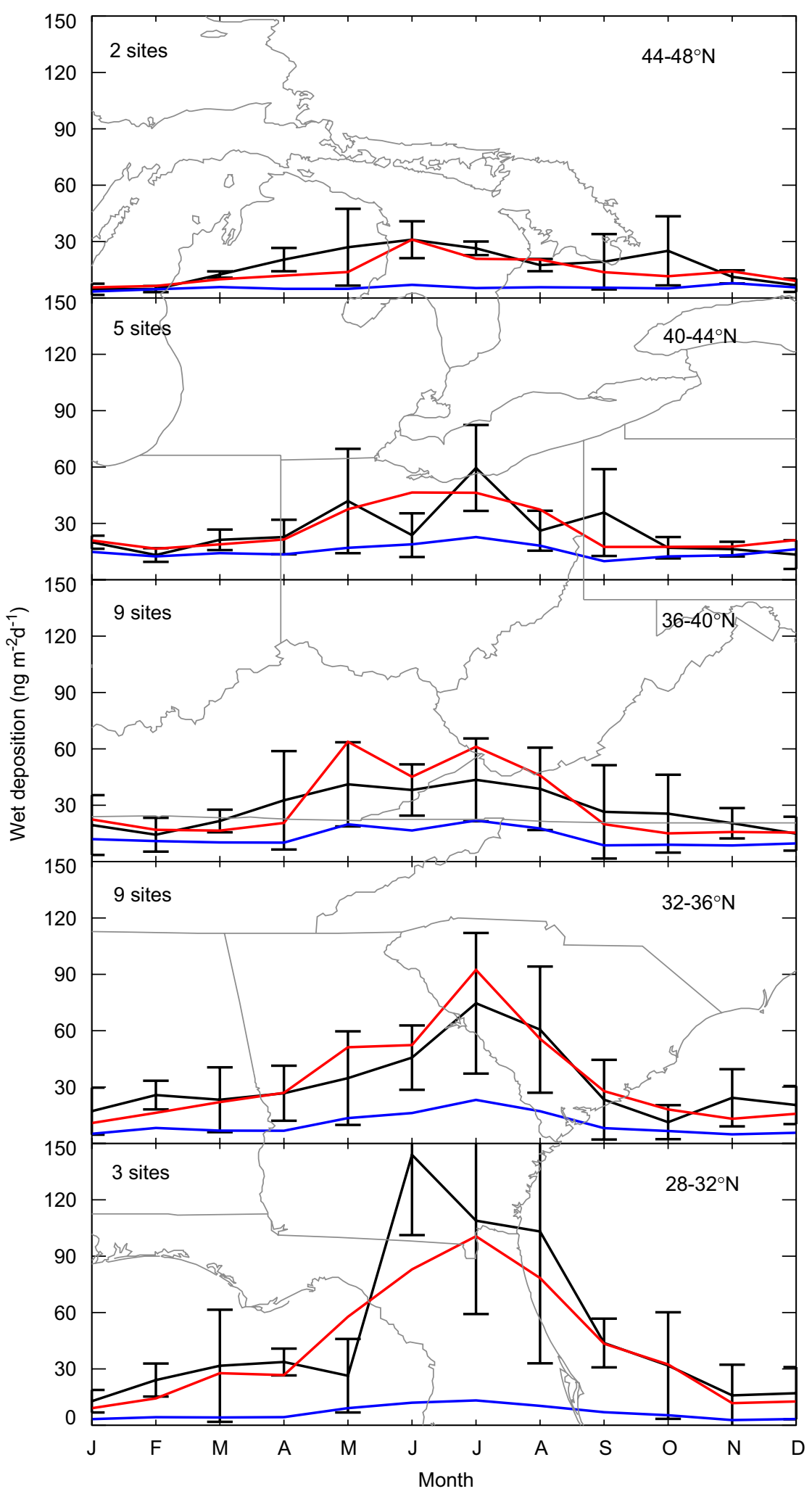


the wintertime contribution to annual wet deposition was lower at Midwest sites in Michigan and Wisconsin $\left(44-48^{\circ} \mathrm{N}\right)$ than at mid-Atlantic sites $\left(36-40^{\circ} \mathrm{N}\right)$. For the 2004-2005 data in Fig. 3, the ratio of average daily deposition in summer (June-August) to winter (December-February) is 6.6 at $28-32^{\circ} \mathrm{N}$ and 4.7 at $44-48^{\circ} \mathrm{N}$. The summer maxima are highest at lower latitudes and decline as latitude increases $\left(119 \mathrm{ng} \mathrm{m}^{-2} \mathrm{~d}^{-1}\right.$ at $28-32^{\circ} \mathrm{N}$, $40 \mathrm{ng} \mathrm{m}^{-2} \mathrm{~d}^{-1}$ at $36-40^{\circ} \mathrm{N}$, and $25 \mathrm{ng} \mathrm{m}^{-2} \mathrm{~d}^{-1}$ at $\left.44^{\circ}-48^{\circ} \mathrm{N}\right)$. The winter minima also decline, although not as much $\left(18 \mathrm{ng} \mathrm{m}^{-2} \mathrm{~d}^{-1}\right.$ at $28-32^{\circ} \mathrm{N}$, $16 \mathrm{ng} \mathrm{m}^{-2} \mathrm{~d}^{-1}$ at $36-40^{\circ} \mathrm{N}$, and $5 \mathrm{ng} \mathrm{m}^{-2} \mathrm{~d}^{-1}$ at $\left.44-48^{\circ} \mathrm{N}\right)$. This north-south difference in the amplitude of the seasonal cycle is consistently found in the different years of the MDN record.

GEOS-Chem reproduces well the seasonal variation of wet deposition of mercury as well as its latitudinal gradient (Fig. 3). There is no significant bias in phase or in amplitude. $\mathrm{Hg}$ (II) contributes $89 \%$ of wet deposition in the model and drives the seasonal variation $(11 \%$ is $\mathrm{Hg}(\mathrm{P})$, which does not vary seasonally). The contribution of North American sources to the wet deposition flux is small, except at northern sites in winter.

Insights into the factors responsible for the seasonal variation in the MDN data can be gained from analysis of the $\mathrm{Hg}(\mathrm{II})$ budget in the model. We find that $59 \%$ of $\mathrm{Hg}$ (II) annual wet deposition in the contiguous US is from scavenging of $\mathrm{Hg}(\mathrm{II})$ in the free troposphere above $850 \mathrm{hPa}(1.5 \mathrm{~km})$. Concentrations of $\mathrm{Hg}(\mathrm{II})$ increase with altitude in GEOS-Chem (Selin et al., 2007), consistent with observations (Swartzendruber et al., 2006; Sillman et al., 2007), and reflecting the long lifetime of $\mathrm{Hg}(\mathrm{II})$ in the free troposphere. Even $\mathrm{Hg}(\mathrm{II})$ within the continental boundary layer (surface to $850 \mathrm{hPa}$ ), which contributes only $41 \%$ of $\mathrm{Hg}(\mathrm{II})$ wet deposition, is mostly from the global pool in the model. We find that $70 \%$ of $\mathrm{Hg}$ (II) in the boundary layer of the continental US is from oxidation and import; only $30 \%$ is from North American anthropogenic emission.

At the northern latitudes of Fig. $3\left(36-48^{\circ} \mathrm{N}\right)$, precipitation amount does not vary significantly throughout the year. However, $\operatorname{Hg}(0)$ oxidation is enhanced by a factor of 3-5 in summer relative to winter, driven by the seasonal variation of $\mathrm{OH}$. Also contributing to the seasonal difference in wet deposition is the much larger scavenging efficiency in summer, when most precipitation is not frozen.

The seasonal variation in the Southeast $\left(28-32^{\circ} \mathrm{N}\right)$ is driven by different processes. At this subtropical latitude, the source of $\mathrm{Hg}$ (II) from $\mathrm{Hg}(0)$ oxidation is only $30 \%$ greater in summer than in winter, and there is little snow. However, unlike the higher latitudes where precipitation is evenly distributed over the year, the Southeast has a summer wet season and winter dry season. Furthermore, summertime precipitation is associated with deep convection that scavenges elevated $\mathrm{Hg}$ (II) from high altitudes. We also examined the seasonal cycle at latitudes $24-28^{\circ} \mathrm{N}$ (southern Florida) and found similar results, both in the model and in the observations.

We examined further the dominant $(59 \%)$ contribution from scavenging of free tropospheric $\mathrm{Hg}(\mathrm{II})$ to the mean mercury wet deposition flux over the US in the model. Fig. 4 shows the model spatial distribution of $\mathrm{Hg}$ (II) concentrations in the free troposphere $(450-850 \mathrm{hPa}$, or about $1.5-6 \mathrm{~km})$. Measurements reported by Sillman et al. (2007) in the free troposphere over Florida (up to $4 \mathrm{~km}$ ) show values between 10 and $250 \mathrm{pg} \mathrm{m}^{-3}$ and increasing with altitude, in the same range as GEOS-Chem modeled values. Measurements from aircraft sampling between 0.8 and $2.6 \mathrm{~km}$ over Florida reported by Guentzel et al. (2001, cited therein to Prestbo, E., Report Submitted to the Florida Department of Environmental Protection, 1996) show $\mathrm{Hg}(\mathrm{II})$ in the range $50-340 \mathrm{pg} \mathrm{m}^{-3}$. We find a subtropical band of high concentrations that reflects the downwelling from the general circulation, with largest values over the East Pacific, where subsidence is the strongest (Selin et al., 2008). This explains the maximum in model wet deposition over Southeast Texas, where the $\mathrm{Hg}(\mathrm{II})$-rich subsiding air interacts with deep convection. The actual observed maximum is over Florida, and this could reflect model error

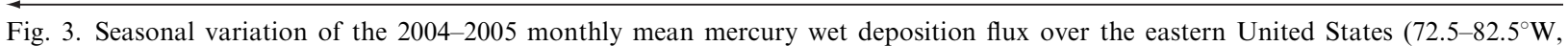
$28-48^{\circ} \mathrm{N}$ ) for different latitudinal ranges. Observations (solid (black online), means \pm standard deviations) are from all MDN sites including at least 15 days of data in each month. The number of sites is shown in the inset. Model results (average of two GEOS-Chem grid boxes) are shown in dashed lines (red online) and the corresponding North American anthropogenic contribution is shown in dotted lines (blue online). MDN codenames for the sites are: $44-48^{\circ} \mathrm{N}$ : MI48, ON07; 40-44 N: IN20, IN34, MI31, PA13, PA30; 36-40 ${ }^{\circ} \mathrm{N}$ : IN21, IN26, IN28, KY10, MD08, OH02, PA37, VA08, VA28; 32-36 N: AL03, GA22, GA40, NC08, NC26, SC05, SC09, SC19, TN11, 28-32 N: FL05, FL32, GA09. Further information and data for these sites are available on the MDN web site at http://nadp.sws.uiuc.edu/mdn/. 


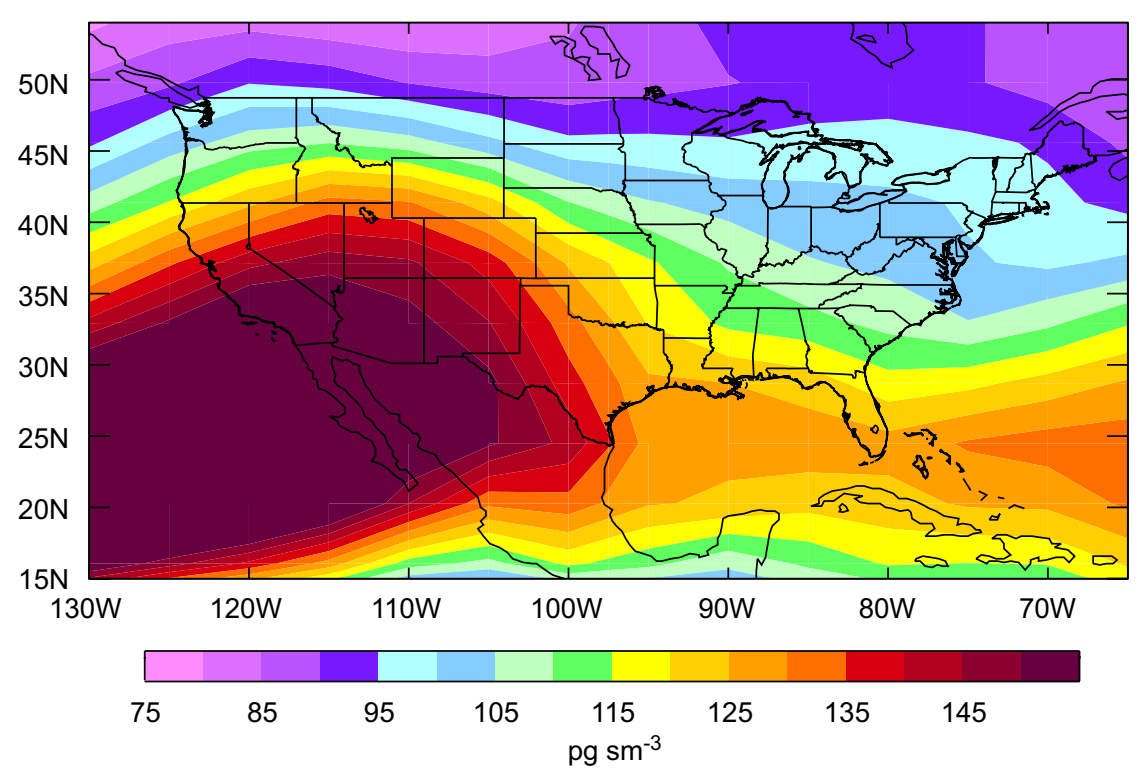

Fig. 4. Simulated annual mean concentration of $\mathrm{Hg}(\mathrm{II})$ in the free troposphere (450-850 hPa, or roughly $1.5-6 \mathrm{~km}$ altitude) for $2004-2005$. Color scale is saturated at the maximum value indicated in the legend. "sm ${ }^{-3}$ " refers to a cubic meter under standard conditions of temperature and pressure, so that " $\mathrm{pg} \mathrm{sm}^{-3}$ " is a mixing ratio unit.

either in the representation of this interaction between downwelling and deep convection or in the $\mathrm{Hg}(0) / \mathrm{Hg}(\mathrm{II})$ redox chemistry of subsiding air masses. Subsidence under dry conditions results in high surface $\mathrm{Hg}(\mathrm{II})$ in the Southwest US in the model, in the range $50-150 \mathrm{pg} \mathrm{m}^{-3}$. The only $\mathrm{Hg}(\mathrm{II})$ measurements in that area to our knowledge are those of Caldwell et al. (2006), who found much lower values, averaging $6.8 \mathrm{pg} \mathrm{m}^{-3}$ over $24-\mathrm{h}$ sampling periods in all seasons, at the MDN site in South-Central New Mexico.

A number of studies have previously interpreted the high mercury wet deposition fluxes observed in southern Florida. Guentzel et al. (2001) found little difference between urban and rural sites in the Florida Atmospheric Mercury Study (FAMS) and concluded that mercury was scavenged from the global pool in the free troposphere, consistent with our results. Bullock et al. (1998) attributed the high mercury deposition in Florida to local sources based on a regional Lagrangian model, but their analysis did not account for the contribution from the global pool, and their simulated wet deposition was low compared with MDN observations. Dvonch et al. (1998, 2005) used daily event-based precipitation data correlated with back-trajectories and chemical tracers for sites in southern Florida in 1995 to argue for a local urban source. Their observed mercury deposition ( $30 \mu \mathrm{g} \mathrm{m}^{-2} \mathrm{yr}^{-1}$ annual average) is much higher than the values in the 2004-2005 MDN data. Local incinerators, which shut down in the 1990s, could explain this difference. Measurements immediately downwind of a large source (before the plume has dispersed on a regional scale) may be expected to show large wet deposition fluxes of mercury, which would not be resolved by our model. This would likely not affect the MDN sites (Fig. 2), which are chosen to be regionally representative and away from local sources.

\section{Source attribution for mercury deposition}

Our successful simulation of the seasonal cycle in the MDN data, which we interpret as largely driven by the global pool of mercury, gives us increased confidence in our ability to use GEOS-Chem to separate North American anthropogenic vs. external contributions to mercury deposition in the United States. Fig. 5 shows the percent contribution of North American anthropogenic emissions to wet and dry annual mercury deposition in the model for 2004-2005. We previously reported similar model results for total mercury deposition in Selin et al. (2007, 2008), but the present results separate wet and dry contributions and also include a number of model updates. A major update relative to Selin et al. (2007) is the inclusion of $\mathrm{Hg}(0)$ dry deposition to land, and a major update relative to Selin et al. 


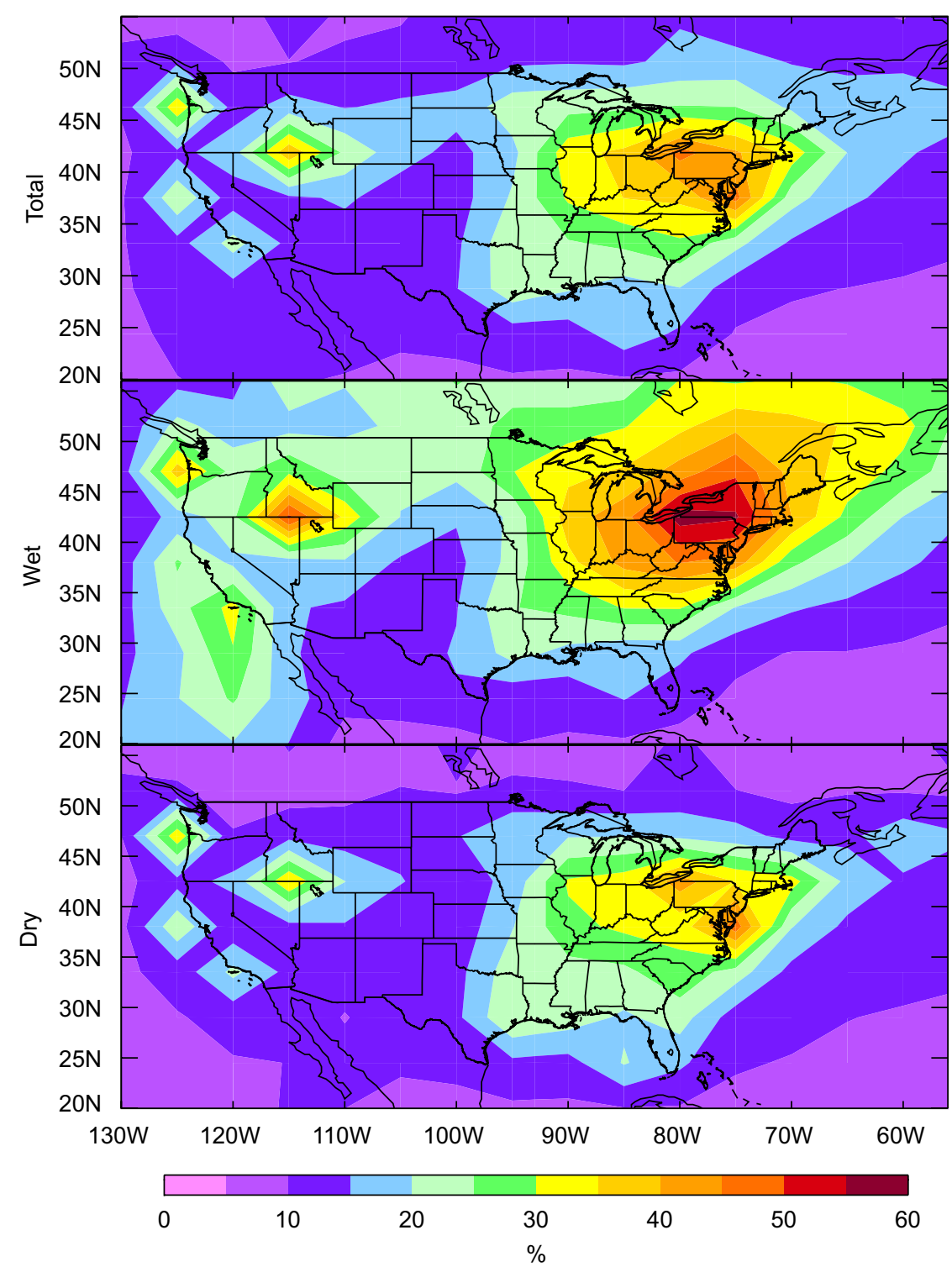

Fig. 5. Percentage contribution from North American primary anthropogenic sources to total (wet plus dry), wet, and dry annual mercury deposition simulated by the model for 2004-2005. North America is defined as the geographical domain shown in the figure.

(2008) is the downward adjustment of $\mathrm{Hg}$ (II) dry deposition and reduction as described in Section 2.

We find that the mean contribution of North American anthropogenic emissions to total deposition over the US is $20 \%$ ( $27 \%$ for wet, $17 \%$ for dry). Both dry and wet deposition show maximum domestic contribution $(50-60 \%)$ in the industrial Midwest and Northeast. North American anthropogenic emissions contribute $4-6 \mu \mathrm{g} \mathrm{m}^{-2} \mathrm{yr}^{-1}$ to wet deposition in a broad area that extends from East Texas through the Midwest and to Pennsylvania, as shown in Fig. 2 (middle panel), but the percentage of total wet deposition that this contributes is comparatively greater in the Northeast, where the contribution from the global pool is relatively low (Fig. 2, bottom panel). The contribution of North American anthropogenic sources to dry deposition generally follows the source distribution of $\mathrm{Hg}(\mathrm{II})$ (Fig. 1), but is highest along coastal areas of the Northeast due to efficient scavenging of $\mathrm{Hg}$ (II) by sea salt in the model (Malcolm et al., 2003; Selin et al., 2007).

Our finding that $60 \%$ of wet deposition in the industrial Midwest originates from North American 
anthropogenic sources can be compared to that of Keeler et al. (2006b), who analyzed event deposition data downwind of sources in the Ohio River Valley at a non-MDN site. They attributed $70 \%$ of wet deposition there to local and regional coal combustion sources using meteorological analyses and multivariate statistical models for trace element concentrations. The wet deposition flux at that site (14-20 $\mu \mathrm{g} \mathrm{m}^{-2} \mathrm{yr}^{-1}$ ) was higher than measured at the MDN sites (Fig. 2), suggesting that it would be impacted by local sources not resolved on the scale of the regional MDN network or the GEOSChem model.

The larger contribution of North American emissions to wet deposition relative to dry deposition in GEOS-Chem is due to $\mathrm{Hg}(0)$ dry deposition, which is predominantly from the global pool. Dry deposition of $\operatorname{Hg}(0)$ is not included in most models and is not routinely measured, so its contribution is highly uncertain, and the MDN data do not offer a constraint on that term.

Compared with Selin et al. (2008), the total model deposition of mercury to the contiguous US is about the same $\left(250 \mathrm{Mg} \mathrm{yr}^{-1}\right)$, but the proportion that is wet has increased (from $21 \%$ to $30 \%$ ) due to the improved dry deposition parameterization. The change in lifetime of $\mathrm{Hg}(\mathrm{II})$ with respect to dry deposition has also shifted the area of maximum North American contribution towards the northeast.

\section{Conclusions}

We have used measured seasonal and spatial variations in mercury wet deposition fluxes over the US from the mercury deposition network (MDN), in comparison to results from a global 3D atmosphere-land-ocean mercury model (GEOS-Chem), to test our understanding of the factors controlling mercury deposition and the contribution from North American anthropogenic emissions.

Wet deposition fluxes in both measurements and the model show a maximum over the Southeast US. The associated latitudinal gradient explains $60 \%$ of the spatial variance in the annual mean data in the East. The MDN flux data in the East also show strong seasonal variation, peaking in summer and minimum in winter. The amplitude of seasonal variation is largest in the Southeast and decreases gradually towards the northern latitudes.

GEOS-Chem is successful in simulating the largescale spatial variability in the MDN observations $\left(r^{2}=0.73\right)$ with little overall bias over the US
$(-1.7 \%)$. It captures the latitudinal gradient, the seasonal phase, and the variation of seasonal amplitude with latitude. We show that these features can be explained by the contribution from the global pool to mercury deposition. We attribute the high mercury deposition over the Southeast to the interaction of the global-scale subtropical downwelling, which supplies elevated $\mathrm{Hg}(\mathrm{II})$ in subsiding air masses, with frequent regional deep convection particularly in summer, which scavenges this free tropospheric $\mathrm{Hg}(\mathrm{II})$. Better characterization of concentrations of $\mathrm{Hg}(\mathrm{II})$ in the free troposphere, where only a few measurements are currently available, would provide further constraints on the processes controlling mercury wet deposition in the United States.

$\mathrm{Hg}$ (II) contributes $89 \%$ of mercury wet deposition in the model and defines the seasonal variation. $\mathrm{Hg}(\mathrm{P})$ accounts for only $11 \%$ and has no seasonal variation. We find in the model that $60 \%$ of $\mathrm{Hg}$ (II) wet deposition in the US originates from scavenging in the free troposphere, where $\mathrm{Hg}(\mathrm{II})$ is elevated by oxidation of $\operatorname{Hg}(0)$, from the global pool. The remainder is from scavenging of $\mathrm{Hg}$ (II) within the US boundary layer, and even there the oxidation of $\mathrm{Hg}(0)$ from the global pool is the principal source. We attribute the summer maximum in mercury deposition in the Southeast to deep convective scavenging of $\mathrm{Hg}(\mathrm{II})$ from high altitudes, similar to the conclusions of Guentzel et al. (2001). We attribute the summer maximum in the Northeast to $\mathrm{Hg}(0)$ photochemical oxidation and to inefficient scavenging of $\mathrm{Hg}(\mathrm{II})$ by snow in winter.

Domestic sources dominate mercury deposition in the model only at northern latitudes in winter when $\operatorname{Hg}(0)$ oxidation is minimum and $\mathrm{Hg}(\mathrm{II})$ scavenging from the free troposphere is inefficient, leaving scavenging of anthropogenic $\mathrm{Hg}(\mathrm{P})$ to be the major contributor. But the overall wet deposition flux of mercury is then very low. Because of its coarse resolution, the model would not capture mercury scavenging from the concentrated plumes immediately downwind of large sources, as measured by a few studies (Dvonch et al., 1998, 2005; Keeler et al., 2006b). The MDN, which deliberately avoids such local influences, does not capture these high values either. Our successful simulation of the MDN data gives us confidence that at least on a regional scale most of the mercury deposition in the US originates from the global pool.

We used the model to derive improved estimates of the percentage contribution of North American 
anthropogenic emissions to annual mean mercury deposition over the US. We find an average contribution of $20 \%$, with values exceeding $50 \%$ only in Pennsylvania and New York State. The GEOS-Chem simulation indicates that much more mercury is deposited to the US by dry rather than wet processes $(70 \%$ versus $30 \%) .42 \%$ of the total mercury deposition to the US in the model is from $\mathrm{Hg}(0)$ dry deposition, which is highly uncertain and for which the MDN data offer no constraints. Further measurements of $\operatorname{Hg}(0)$ deposition velocities over a range of ecosystem types are needed to better quantify this global contribution to mercury deposition in the US.

\section{Acknowledgments}

This work was funded by the Atmospheric Chemistry Program of the US National Science Foundation and by a US Environmental Protection Agency (EPA) Science to Achieve Results (STAR) Graduate Fellowship to NES. EPA has not officially endorsed this publication and the views expressed herein may not reflect the views of the EPA.

\section{Appendix A. Supplemental materials}

Supplementary data associated with this article can be found in the online version at doi:10.1016/ j.atmosenv.2008.02.069.

\section{References}

Bey, I., Jacob, D.J., Yantosca, R.M., Logan, J.A., Field, B.D., Fiore, A.M., Li, Q.B., Liu, H.G.Y., Mickley, L.J., Schultz, M.G., 2001. Global modeling of tropospheric chemistry with assimilated meteorology: model description and evaluation. Journal of Geophysical Research-Atmospheres 106 (D19), 23073-23095.

Bullock, O.R., Brehme, K.A., Mapp, G.R., 1998. Lagrangian modeling of mercury air emission, transport and deposition: an analysis of model sensitivity to emissions uncertainty. Science of the Total Environment 213, 1-12.

Bullock, O.R., Atkinson, D., Braverman, T., Civerolo, K., Dastoor, A., Davignon, D., Ku, J.-Y., Lohman, K., Myers, T., Park, R., Seigneur, C., Selin, N.E., Sistla, G., Vijayaraghavan, K., 2007. The North American Mercury Model Intercomparison Study (NAMMIS). Part 2: comparisons to observed wet deposition of mercury, in review.

Caldwell, C.A., Swartzendruber, P., Prestbo, A., 2006. Concentration and dry deposition of mercury species in arid south central New Mexico (2001-2002). Environmental Science and Technology 40, 7535-7540.

Dvonch, J.T., Graney, J.R., Marsik, F.J., Keeler, G.J., Stevens, R.K., 1998. An investigation of source-receptor relationships for mercury in south Florida using event precipitation data. Science of the Total Environment 213, 95-108.

Dvonch, J.T., Keeler, G.J., Marsik, F.J., 2005. The influence of meteorological conditions on the wet deposition of mercury in Southern Florida. Journal of Applied Meteorology 44, 1421-1435.

Glass, G.E., Sorensen, J.A., 1999. Six-year trend (1990-1995) of wet mercury deposition in the Upper Midwest. USA. Environmental Science and Technology 33 (19), 3303-3312.

Guentzel, J.L., Landing, W.M., Gill, G.A., Pollman, C.D., 2001. Processes influencing rainfall deposition of mercury in Florida. Environmental Science and Technology 35, 863-873.

Hall, B., 1995. The gas phase oxidation of elemental mercury by ozone. Water, Air, and Soil Pollution 80, 301-315.

Keeler, G.J., Gratz, L.E., Al-Wali, K.I., 2006a. Long-term atmospheric mercury wet deposition at underhill, Vermont. Ecotoxicology 14, 71-83.

Keeler, G.J., Landis, M.S., Norris, G.A., Christianson, E.M., Dvonch, J.T., 2006b. Sources of mercury wet deposition in Eastern Ohio, USA. Environmental Science and Technology 40, 5874-5881.

Lin, C.-J., Pehkonen, S.O., 1999. The chemistry of atmospheric mercury: a review. Atmospheric Environment 33 (13), 2067-2079.

Lindberg, S.E., Stratton, W.J., 1998. Atmospheric mercury speciation: concentrations and behavior of reactive gaseous mercury in ambient air. Environmental Science and Technology $32,49-57$.

Lindberg, S., Bullock, R., Ebinghaus, R., Daniel, E., Feng, X., Fitzgerald, W., Pirrone, N., Prestbo, E., Seigneur, C., 2007. A synthesis of progress and uncertainties in attributing the sources of mercury in deposition. Ambio 36 (1), 19-32.

Liu, H., Jacob, D.J., Bey, I., Yantosca, R.M., 2001. Constraints from $210-\mathrm{Pb}$ and $7-\mathrm{Be}$ on wet deposition and transport in a global three-dimensional chemical tracer model driven by assimilated meteorological fields. Journal of Geophysical Research 106 (D11), 12, 109-112, 128.

Lohman, K., Seigneur, C., Edgerton, E., Jansen, J., 2006. Modeling mercury in power plant plumes. Environmental Science and Technology 40, 3848-3854.

Malcolm, E.G., Keeler, G.J., Landis, M.S., 2003. The effects of the coastal environment on the atmospheric mercury cycle. Journal of Geophysical Research 108 (D12), 4357.

Mason, R.P., Lawson, N.M., Sheu, G.R., 2000. Annual and seasonal trends in mercury deposition in Maryland. Atmospheric Environment 34 (11), 1691-1701.

National Atmospheric Deposition Program, 2007. Mercury deposition network (MDN): A NADP network. NADP Program Office, Illinois State Water Survey, Champaign, IL. 〈http://nadp.sws.uiuc.edu/mdn/ 〉, accessed 29 May 2007.

NEI, 1999. National Emission Inventory Documentation and Data, US Environmental Protection Agency.

Pacyna, E.G., Pacyna, J.M., Steenhuisen, F., Wilson, S., 2006. Global anthropogenic mercury emission inventory for 2000. Atmospheric Environment 40 (22), 4048-4063.

Pal, B., Ariya, P.A., 2004. Gas-phase HO-initiated reactions of elemental mercury: kinetics and product studies, and atmospheric implications. Environmental Science and Technology 21, 5555-5566.

Poissant, L., Pilote, M., Beauvais, C., Constant, P., Zhang, H.H., 2005. A year of continuous measurements of three atmospheric mercury species (GEM, RGM and Hg-p) in southern 
Quebec, Canada. Atmospheric Environment 39 (7), $1275-1287$.

Seigneur, C., Wrobel, J., Constantinou, E., 1994. A chemical kinetic mechanism for atmospheric inorganic mercury. Environmental Science and Technology 28, 1589-1597.

Seigneur, C., Vijayaraghavan, K., Lohman, K., Karamchandani, P., Scott, C., 2004. Global source attribution for mercury deposition in the United States. Environmental Science and Technology 38 (2), 555-569.

Selin, N.E., Jacob, D.J., Park, R.J., Yantosca, R.M., Strode, S., Jaegle, L., Jaffe, D.A., 2007. Chemical cycling and deposition of atmospheric mercury: global constraints from observations. Journal of Geophysical Research 112, D02308.

Selin, N.E., Jacob, D.J., Yantosca, R.M., Strode, S., Jaegle, L., Sunderland, E.M., 2008. Global 3-D land-ocean-atmosphere model for mercury: present-day vs pre-industrial cycles and anthropogenic enrichment factors for deposition. Global Biogeochemical Cycles, in press, doi:10.1029/2007GB003040.

Sillman, S., Marsik, F.J., Al-Wali, K.I., Keeler, G.J., Landis, M.S., 2007. Reactive mercury in the troposphere: model formation and results for Florida, the northeastern US and the Atlantic Ocean. Journal of Geophysical Research 112, D23305.
Sommar, J., Gårdfeldt, K., Strömberg, D., Feng, X., 2001. A kinetic study of the gas-phase reaction between the hydroxyl radical and atomic mercury. Atmospheric Environment 35, 3049-3054.

Strode, S., Jaegle, L., Selin, N.E., Jacob, D.J., Park, R.J., Yantosca, R.M., Mason, R.P., Slemr, F., 2007. Global simulation of air-sea exchange of mercury. Global Biogeochemical Cycles 21, GB1017.

Strode, S., Jaeglé, L., Jaffe, D.A., Swartzendruber, P.C., Selin, N.E., Holmes, C., Yantosca, R.M., 2008. Trans-Pacific transport of mercury. Journal of Geophysical ResearchAtmospheres, in press. doi:10.1029/2007JD009428.

Swartzendruber, P., Jaffe, D.A., Prestbo, E.M., Smith, J.E., Weiss-Penzias, P., Selin, N.E., Jacob, D.J., Park, R.J., Strode, S., Jaegle, L., 2006. Observations of reactive gaseous mercury at the Mt. Bachelor Observatory. Journal of Geophysical Research 111, D24301.

Vanarsdale, A., Weiss, J., Keeler, G., Miller, E., Boulet, G., Brulotte, R., Poissant, L., 2005. Patterns of mercury deposition and concentration in Northeastern North America (1996-2002). Ecotoxicology 14 (1-2), 37-52.

Wesely, M.L., 1989. Parameterization of surface resistances to gaseous dry deposition in regional-scale numerical models. Atmospheric Environment 23 (6), 1293-1304. 